Benedicte Bull* (D) and Jason Miklian

\title{
Towards global business engagement with development goals? Multilateral institutions and the SDGs in a changing global capitalism
}

\begin{abstract}
Over the last decades, encouragement of business engagement with environmental and socio-economic development has gained prominence due to the perceived weakening of states and multilateral institutions against the forces of global capitalism. Different ways of encouraging changes in business behavior have been promoted, such as the formation of public/private partnerships, corporate social responsibility initiatives, and other forms of non-binding organizational arrangements. However, there is no real consensus on the desired role of business in development, what the best policies for global development are, or what "development" itself is and should be defined as. Indeed, precisely as a formal consensus has been reached on the broad agenda of the United Nations Sustainable Development Goals, a narrower agenda focusing on industrialization, modernization, and economic growth is promoted by new actors, many originating in the Global South. This special issue asks how the emergence of new actors and the adaptation by global institutions affect the ways in which business engages with development. This introductory article positions the issue's contributions into three discussions: exploring issues of global coherence and division on key debates; understanding how new actors are reshaping the public-private divide; and assessing how disconnects within discourse on business and development can amplify negative societal consequences in fragile settings of weak governance.
\end{abstract}

Keywords: development, multilateral institutions, sustainable development goals, corporate social responsibility, public/private partnerships

doi:10.1017/bap.2019.27

*Corresponding author: Benedicte Bull, professor, Centre for Development and the Environment, University of Oslo; Email: benedicte.bull@sum.uio.no

Jason Miklian, post-doctoral fellow, Centre for Development and the Environment, University of Oslo; Email: jason.miklian@sum.uio.no 


\section{Introduction}

What role should business play in global development? This question cuts to the core of today's global betterment agendas, driving governmental, multilateral, and business policies by asking how some of the world's most powerful actors can best help improve the lives of the poorest and most vulnerable in society. Business engagement with environmental and socio-economic development has gained prominence due to the perceived weakening of states and multilateral institutions against the forces of global capitalism. ${ }^{1}$ Encouraging business engagement in development became a way to rescue the ideas of a global liberalism from critics who saw predatory capitalism subsuming social goals. ${ }^{2}$ Businesses, particularly large multinational companies (MNCs), are now seen as agents able to shape their societal context through political influence or their own environmental and social practices, rather than simply responding to market opportunities and being subject to state regulations. ${ }^{3}$

As a consequence, multilateral development institutions have encouraged business participation in development efforts through different forms of public/ private partnerships (PPPs), corporate social responsibility (CSR) initiatives, and other forms of non-binding organizational arrangements. The United Nations Sustainable Development Goals (SDG) agenda is arguably the strongest framework yet. The SDGs consist of 17 Goals and 169 Targets, decided by global consensus, that aim to tackle a wide variety of global development challenges. In support, the UN encourages businesses from across the world to participate in development through the SDGs, whether through individual commitments or participation in development partnerships.

The problem, of course, is that the question "What role should business play in global development?" can also be seen as a red herring. Implying that there is a defined positive role that business can and should play in development assumes that there is consensus on the desired role of business in society, on what the best policies for global development are, and, not least, on what "development" itself is and should be defined as. In practical terms, business adoption of the SDGs coupled with the broader upsurge of initiatives to encourage business engagement in development as responsible social actors must be contextualized within our shifting playing field of global capitalism, with an increasing number and scale of companies emerging out of very different state-business frameworks than

\footnotetext{
1 Matten (2004); Pattberg (2005).

2 Bull and McNeill (2007), chapter 1.

3 Biersteker and Hall (2002); Cutler et al. (1999); Ougaard and Leander (2010).
} 
Western ones. ${ }^{4}$ These new actors often buttress and quietly subvert global business and development norms simultaneously. For example, some scholars see a stark contrast between Western and Chinese state-capital nexuses and actors. ${ }^{5}$ Yet, China and Chinese firms place a strong emphasis on multilateralism and/or bilateralism and on contributing to global development through joint state-business endeavors, including the SDGs, but also through separate initiatives (e.g., the Belt and Road Initiative) and support for new development institutions with priorities that they see as more aligned to their worldview, such as the Asian Infrastructure Bank. ${ }^{6}$ This occurs as the United States has turned inwards and criticized or withdrawn from a series of multilateral initiatives, opening the door for new actors to stake a larger claim to legitimacy. ${ }^{7}$

Today, we see the emergence of a rising tension. While powerful Global North states are indeed driving deeper engagement by business in a broad new framing of development as social empowerment through platforms, including but not limited to the UN SDGs, a number of key Global South economies are promoting, instead, a return to the older concept of development as only industrialization and economic growth. The motivation for this special issue is thus to study how adaptation by global institutions and emergence of new actors affect the ways in which companies engage with development. Common questions addressed by the articles herein include: Do non-Western companies engage differently with PPPs and CSR than their Western counterparts? To what extent are these shifts transformed through actors that may incorporate very different understandings of state-business relations? How do different ideas of business and development manifest themselves for and upon local populations? Through a series of theoretical and empirical contributions, we seek to share new insights into the practical, policy, and scholarly implications of the answers to these questions.

After a brief review of recent debates on business in multilateral development efforts, this introductory article positions the issue's contributions into three discussions: exploring issues of global coherence and division on key concepts that cut across both business and development actors; understanding how new actors are reshaping the public-private divide and what their motives are for doing so; and assessing how disconnects within discourse on business and development can, when incorporated into policies that are intended to strengthen economies and improve social cohesion, instead amplify negative societal

4 Or what has been called different state-capital nexuses. See, e.g., Van Apeldoorn et al. (2012).

5 De Graaf and Van Apeldoorn (2017), González Vicente, this issue.

6 Stunkel (2016); Zhang (2017).

7 Ikenberry (2018); Miklian (2019b). 
consequences in fragile settings of weak governance. We close with a brief discussion on positionality and future research opportunities.

\section{Business and global development institutions}

Ideas for how to involve business in development work have changed significantly since the establishment of the Western-led multilateral development institutions after World War II. Still, business has been involved from the day of their establishment. To wit, at the UN's founding conference in June 1945, although only one business association was allowed official accreditation (the International Chamber of Commerce), several others expressed their interest. ${ }^{8}$ The dominating ideology underpinning the development efforts of most of the global institutions at the time was rooted in modernization theory, emphasizing economic growth, technological upgrading, and industrialization as keys to bringing so called "backwards areas" out of their misery. While modernization theorists were frequent critics of the laissez-faire ideas of, e.g., David Ricardo, they were not antibusiness. ${ }^{9}$ Rather, they saw it as a key challenge to attract sufficient capital through private business to areas characterized by lack of infrastructure, access to technology skilled labor, and "entrepreneurial spirit." 10 Given these conditions, they saw it as the role of the state, assisted by multilateral institutions, to make capital available and to invest to make up for the other "deficiencies." As such, the state was the main development agent, but the goal of state activity should be to facilitate the also private business investment. ${ }^{11}$

The apparent contradiction between the multilateral institutions' encouragement and support of domestic state interventions in the economy and the effort to create a liberal global framework for movement of goods and capital, was, by John Ruggie, famously labelled the "compromise of embedded liberalism." ${ }^{12}$ This, he argued: "unlike the economic nationalism of the thirties, would be multilateral in character; unlike the liberalism of the gold standard and fee trade, its multilateralism would be predicated upon domestic interventionism."13 The latter was

\footnotetext{
8 Tesner and Kell (2000).

9 Helleiner (1996).

10 Modernization theories are often equated with the rather simplified and politicized contribution by Walt Rostow. However, the writings of early economists, such as Paul Rosenstein-Rodan, W. Arthur Lewis, Albert O. Hirschman, and Ragnar Nurkse, provide much more profound accounts of key aspects of development problems. See Bull and Bøås (2010a) for a discussion.

11 Bull and Bøås (2010a).

12 Ruggie (1982).

13 Ibid., 393.
} 
seen as a necessary condition for the former, to cushion the population from the change and dislocation resulting from international liberalism. ${ }^{14}$ The compromise expressed itself in the support for global institutions changed with liberalizing global markets for goods and finance (including the Generla Agreement on Tariffs and Trade [GATT] and the International Monetary Fund [IMF]), while other parts of the system, such as the World Bank, prescribed strengthening the role of the state through social policies, public investments, and creation of state owned enterprises.

While influential, the compromise was contested both by laissez-faire liberalists arguing against state intervention, and by the more radical dependency theorists rejecting international liberalism. ${ }^{15}$ The latter dominated institutions, such as the United Nations Conference of Trade and Development (UNCTAD), and advocated for ideas of a more regulated world trade that could compensate for the volatility and the structural inequality inherent in unfettered global capitalism. Dependency theory of various strands challenged not only the clear distinction between national and international economies, but also the idea of a clear separation between states and the private sector. Specifically, multinational companies were considered allies of oppressing elites in developing countries and more of a predator than positive economic development actor. ${ }^{16}$ By the early 1980s, laissez-faire policies were resurgent, helped by the conservative Reagan/ Thatcher movements but also by increasing evidence of numerous failures of state-led development efforts. ${ }^{17}$ In this period, business was increasingly considered the agent to drive development forward, replacing previous discourses focusing on the state as the main development agent. ${ }^{18}$

Globalization's expansion after the end of the Cold War exacerbated the power imbalances between wealthy MNCs and host states incapable of providing the most basic social protection to their citizens. Coupled with visible examples of firms profiting from fragile spaces, while the societies themselves were harmed, this system generated new calls for business to take on more direct social responsibilities. One result of this was that, by the 1990s, global institutions actively sought business participation in decision-making and implementation of what were presumed to be common goals. For example, the 1992 Rio Summit was the

\footnotetext{
14 Ruggie (1997).

15 Helleiner (2019).

16 Bull and Bøås (2010b).

17 E.g., Kruger (1978), Balassa (1982).

18 An emblematic document in this process was the World Development Report of 1997: The State in a Changing World, which described the change from a proactive developmental state to one that principally should seek to facilitate the strengthening of the private sector.
} 
first global summit where business was an active partner. Particularly, the International Chamber of Commerce played an important role in the organization and development of the agenda, along with key non-governmental organizations (NGOs). ${ }^{19}$ The presence of business in similar meetings increased over the decade to follow, while the more critical UN Center on Transnational Corporations (UNCTC) was disbanded in 1995. However, the discourse on volunteerism was increasingly a way to allow businesses to contribute to development without being subject to state regulation. ${ }^{20}$

The normalization of business as a participant in development decision making and implementation spurred a broad debate in the late 1990s and early 2000s on the implications of this for the multilateral development system. Would it imply a UN "bluewashing" of corporate transgressions as businesses also became formal partners in local development activities?21 Does business participation in development undermine the democratic principles and legitimacy of the system?22 Or does it simply cement Western-led and designed market orientation and neoliberalism as basic principles of global development efforts through "market-multilateralism," incorporating business as a main actor and wherein key principles of global capitalism form what are considered the "legitimate" boundaries for possible multilateral action? ${ }^{23}$ During the decade that followed, various UN organizations, as well as the UN General Assembly, made efforts to streamline business involvement in development in order to ensure that it would be in accordance with UN goals and to ensure the efficiency of initiatives to form partnerships. However, the implications of these endeavors for the global development institutions remained unclear.

Yet, they also incorporate a set of informal practices, networks, and groupings, and sometimes the difference between informal and formal organizations is blurred. For example, the UN Global Compact (UNGC), a network designed to link development and business actors in pursuit of the SDGs, is a UN subsidiary but includes business guidelines that are much more informal than typical UN initiatives. An increasing number of private organizations and networks that promote a "development" agenda also contain formal and informal components by design. One example is the Business and Human Rights platform, consisting of both multilateral organizations like the UN but also NGOs and activists groups more commonly associated with "naming and shaming" businesses. These inter-

19 Bull and McNeill (2007), chapter 1.

20 Ruggie (1997, 2008); Mayer and Gereffi (2010).

21 Berliner and Prakash (2015); Schouten and Miklian (2018).

22 Bexell and Mörth (2010).

23 Bull and McNeill (2007). 
connections can be seen as manifested in recent promises by large investment houses to mandate "social good" and development action by the companies that they choose to invest in, with the support (yet non-binding guidance) of various Business and Human Rights bodies. ${ }^{24}$

While nearly all big firms today-Western and non-Western-claim to be engaged in development issues, in many cases, with global development institutional support, we have also seen the return of state-led development ideas. ${ }^{25}$ Indeed, while the so called "global development agenda" is always somewhat fragmented and contradictory, it is possible to identify a return to ideas of development understood in the classical modernization sense as industrialization, technological upgrading, and economic growth. ${ }^{26}$ This is, to a significant extent, a result of the rise of a set of leaders and movements in emerging economies that espouse ideas that compete with the liberal ideas of a clear distinction between the state and the private sector and the limitation of the role of the state in the economy. ${ }^{27}$ This represents a break with the tendency starting in the 1970s of amplifying the field of development research and the idea of development to include a broad array of goals and at multiple levels of society, in accordance with not only economically, but also politically and socially liberal and pluralist ideas. These include human and group rights, empowerment, democratization, gender equality, institutional strengthening, protecting biodiversity, mitigation and adaptation to climate change, reducing poverty and inequality, securing basic needs, health, and education. $^{28}$

The core irony, then, is that the resurgent attraction of this narrow, classic modernization concept of development as industrialization and economic growth has occurred precisely at the time when a broad global development agenda was solidified for the first time-through first the Millennium Development Goals and later the SDGs. The articles of this special issue explore this contradiction from several different angles, as well as the broader implications of the tensions between these dueling forces upon what it means for business engagement with development in the twenty-first century.

24 Miklian, Alluri, and Katsos (2019).

25 Schneider (2016).

26 Bull (2015).

27 Amsden (2001).

28 Bull and Bøås (2012, 2010c). 


\section{The SDGs: transforming or preserving business practice?}

First, several articles examine how the understanding and framing of key concepts to encourage business engagement with development goals shape business practices for development. Within global development institutions, ideas such as PPP, CSR, or "sustainable development" may be influential and may generate policies that have positive impacts upon development in practice, but they can also be distorted, ignored, or manipulated and can lead to ineffective or even counter-productive initiatives. ${ }^{29}$ To wit, the scope and practice of concepts, such as "sustainable development," have changed significantly, not only through being "filtered" by the needs and demands of global institutions, but also in the process of having become embedded in a complex set of business principles and guidelines that operate under highly different conditions and incentive structures. ${ }^{30}$ The question then is how these business practices are being shaped.

Ralf Barkemeyer (this issue) takes the first cut at this question, asking whether CSR practices are either a substitute for or simply a mirror of state regulations. This, as he argues, revolves around the function of CSR in the wider governance mix and whether state-led or predominantly voluntary initiatives can effectively serve to promote corporate social performance. This question also speaks directly to the SDGs, which are increasingly a framework for CSR practices. The SDGs are deliberately formulated so as to enable the engagement of multiple actors. As noted by Biermann et al. the kind of governance in which the UN organizations are involved related to the SDGs, is not a regular hierarchical form of governance, but rather "governance by goal-setting." 31 This means that although a complex set of indicators set to monitor the results of the general efforts to reach the SDGs are developed, $^{32}$ there are few actual monitoring mechanisms with punitive capabilities. Nevertheless, the SDGs are meant to transform global development towards being more inclusive and greener, among many other goals. To what extent then, are businesses' voluntary efforts able to transform global development?

The SDGs have revitalized a concept that emerged in the 1990s as a means to encourage the compatibility between business practices and broader development goals, namely PPPs. But in the process, the very meaning and purpose of a "PPP" can be reshaped almost beyond recognition. As Bull and McNeill (this issue) show,

29 Bøås and McNeill (2003).

30 Barkmeyer et al. (2014).

31 Bierman et al. (2017).

32 Fukuda-Parr and McNeill (2019). 
while the number of registered partnerships to support the SDGs has increased enormously, their content varies-ranging from global arrangements that seek to change the operations of markets and production patterns, to local aid projects and philanthropic ventures. PPPs are flexible enough to be embraced by a variety of actors with different agendas, emerging in contexts characterized by different state-business relations. For example, U.S. companies are involved in a large amount of partnerships with varied profiles, focusing on policy change, resource mobilization, and change of attitudes and consumption patterns. In contrast, Chinese PPPs are growing rapidly in number but are mostly project based. Chinese firms tend to undertake investments or provide goods or services in partnership with Chinese governmental actors, and very few of these partnerships appear as distinctly privately driven.

Gonzalez-Vicente (in this issue) analyzes the Chinese use of PPPs through state-coordinated investment partnership as a part of its Belt and Road Initiative (BRI). In line with Bull and McNeill, he argues that China promotes accumulation and sovereignty regimes that transnationalize features of the Chinese political economy into new "spatial fixes." This does not mean, however, that Chinese companies relate in a fundamentally different way to ideas emerging in the context of multilateral cooperation. Differences in their approach to partnerships result rather from differences in whom they may count as their main stakeholders, be it shareholders, governments, markets, or local communities. In most cases, joining a partnership and registering it in the UN registry is an attractive option for a company to enhance its reputation-whether locally or globally-at minimal cost or risk.

The SDGs strong impact on discourse, yet relatively weak impact on practice is also observed in Banik and Li's article on the impact of SDG priorities on Chinese companies' CSR practices. The Chinese government has repeatedly emphasized the transformative potential and nature of the SDGs. However, Banik and Li show that this interest reflects a combination of the Chinese government's desire to establish and further improve their image vis-à-vis the general global public, satisfy central government directives, gain a competitive edge with regard to rivals, and generally improve corporate culture within the organization. ${ }^{33}$ The main motive of the companies is to cultivate social, economic, and political relationships within their local area of operation. Thus, the goals and motives are related to the SDGs as such but prioritize first and foremost stakeholder relations as a means to improving their business performance. The connection with the SDGs exists due to the broadness of the SDGs themselves, as a sort of clearing house for all business CSR activities in some way, shape, or form. This is not very

33 Banik and Lin (2019). 
different in practice from what companies based in other parts of the world do, with the modification that what Chinese companies consider their main motivation for change in discourse is the relationship to the local and national government, whereas companies elsewhere would typically place stronger emphasis on market and shareholder relations.

One conclusion that can be drawn from the above is that the SDGs have transformed corporate discourses, but have had a much weaker impact upon corporate practices. Barkemeyer's article takes this finding a step further, exploring how particular features of the governance structures in which businesses are embedded, as well as voluntary initiatives, shape not only the discourse of CSR but also corporate social performance (CSP). ${ }^{34}$ Studying a sample of 264 large companies situated in emerging and developing economies, they study the effect of both UNGC attachments and "voice and accountability" indicators in governance contexts, comparing the relative impact of these two factors on corporate human rights and environmental and community performance. Rather than finding, perhaps expected, blanket effects of either national governance or international voluntary initiatives, they find instead that national governance was most influential on environmental and human rights performance. These findings support the "mirror" argument above, whereas a more mixed picture emerges for community performance. Further, the observed positive impact of UNGC participation across all three CSP dimensions may support the view that these types of initiatives help raise awareness of social challenges, as more proactive companies (and thus better corporate social performers) might be drawn to the initiative rather than the UNGC improving member CSP.

What emerges from a joint reading of these contributions is that voluntary initiatives, such as the UNGC have the potential for improved corporate impact through their extensive participation, but thus far the SDGs have had little impact in changing corporate practices through their promised transformative framework for businesses.

\section{Understanding the public/private divide in new contexts}

So, what kinds of new business roles do we see emerging in practice in these contexts? What shifting divisions of roles between public and private actors are emerging, and what are the implications of these shifts upon business practices?

34 Barkmeyer (2019). 
Although the SDGs were formulated in such a way as to allow for multiple actors to engage with them, there is little doubt that the very structure of participation and engagement was modeled on a notably Western distinction between the public and the private, including clear boundaries between the state, NGOs, and business. As we know, that does not reflect operational realities in every corner of the world.

Gonzales-Vicente makes an empirical study of this disconnect, exploring the links between business development in China and the impacts of Chinese investments overseas. He argues that the driving force of overseas investment, now "packaged" in the BRI initiative, is a crisis of overcapacity at home. He argues that the BRI is the result of a gradual evolution of capitalist logic through the tight relationship between Chinese political and economic power, a process that rested on the "proletarianization" of Chinese workers themselves. The statecentric flexible coordination of large foreign direct investment projects conditions the development impact of Chinese investments overseas. These investments can thus neither be considered to be purely private nor a relic of an inefficient statecontrolled past. Individually, the projects prioritize profit maximization. Collectively, they prioritize the global expansion of Chinese capitalism.

In practice, the impact of Chinese investments on the evolution of state business relations in recipient countries is diverse. Gonzales-Vicente points to three ways in which Chinese conglomerated investments may undermine the evolution of developmental state-business relations and potentially be conducive to the misappropriation of state funds by host governments. First, the fact that deals are signed at the highest diplomatic level can often result in lower transparency and accountability. Second, government-to-government negotiations have also prevented open and transparent bids, with some deals remaining opaque and questionable. And finally, there is a lack of reliable public data, unwillingness to sign up to transnational transparency and responsibility standards, and lack of civil society or other institutional networks to monitor and hold businesses accountable within China. ${ }^{35}$

\section{Disconnects in practice: business development discourse meets complex realities}

When studying the panoply of business collaborations for development, we include initiatives over an immense scale. Naturally, any such widely-cast umbrella can display a wide range of intended and unintended consequences.

35 González-Vicente (2019). 
Several articles in this issue explore one such unintended consequence in particular: how the same business-development policies that can strengthen economies and improve social cohesion in some settings can instead amplify social disintegration and violence in fragile settings of weak governance. Critics of business-development tie-ups tend to focus on the misadventures of companies when they try to play a development role, ${ }^{36}$ or on the consequences of letting a for-profit actor with different goals and objectives than development entities have a say in social improvement. ${ }^{37}$ Further, comparative focus on Western firms and Western-style CSR with their Global South counterparts tends (with notable exceptions) to marginalize Global South business-development contributions, portraying them as less sophisticated, less effective, or less substantial when they are often simply different. Following, newer actors in these spaces like Chinese and Indian firms are often seen as less morally-driven than their Global North counterparts (or at least more profit-driven) and less concerned about local social issues, thereby offering a less valuable engagement in business-development initiatives. ${ }^{38}$

Several articles in this issue suggest instead that other markers (such as firm sector, firm size, or firm structure) may have more distinctive comparative value. ${ }^{39}$ Returning to the "mirror versus substitute" debate referred to above, Barkemeyer (2019) discusses the function of CSR in the wider governance mix and whether state-led or predominantly voluntary initiatives can effectively serve to promote corporate social performance. Whilst they find the mirror view to be dominant, they also observe a multiplicity of patterns depending on the sustainability issue at stake, as well as the specific governance dimension that is examined.

One lingering puzzle of business and sustainable development is why and how the joint macro impact of the influx of business and development actors can be negative when their individual actions, particularly that of growing economies to stimulate development, may be considered to be positive ${ }^{40}$ Moreover, both multilateral institutions and multinational firms have difficulty responding effectively to rapid political changes, creating situations where negative consequences of well-intended business and development aims are perpetuated and exacerbated instead of ameliorated. To help unpack the foundations of this paradox, Miklian asks: How can we better understand the complex interaction effects when businesses and international government agencies become partners in social develop-

36 Miklian (2017); Miklian et al. (2018).

37 E.g., Richmond (2017).

38 Moon and Shen (2010); Yang and Rivers (2009).

39 Baanik and Lin (2019); Barkemeyer (2019).

40 Ganson et al. (2019); O'Connor and Labowitz (2017); Oetzel and Miklian (2017). 
ment? ${ }^{41}$ Using a novel methodology that employs field experiences of Heineken in the Democratic Republic of Congo, ethnic cleansing in Myanmar, and the UNGC in Dubai, Miklian presents the human impact of several key multi-stakeholder business-development policies. He argues that business-development ties often result in complex, unforeseen, and multivariate consequences where multilateral-supported economic growth and conflict can co-exist. He further shows how these business and development frameworks and policies can impact upon livelihoods of the most vulnerable in such settings, also in ways that can be understood as simultaneously positive and negative.

Ganson and M'cleod similarly explore the dynamics by which the promotion of private sector development (PSD), particularly through FDI, interacted in complex ways with pre-existing causes of fragility in Sierra Leone, from the end of the civil war through the Ebola epidemic. Contrary to the rhetoric of peace dividends and increased stability by government officials and international institutions, their analysis finds that PSD remained one of the vectors for persistent poverty, increasing inequality, and growing instability. Efforts to promote PSD were often perverted as the state itself was implied in citizen insecurity; civil society grew frustrated and regional and ethnic tension were reinforced. Ganson and M'cleod then model the ways in which PSD became entangled with sociopolitical conflict and other dynamics of fragility, helping to explain the outcomes of-and perhaps open new directions for-policy interventions and programmatic implementation of PSD.

This issue also explores selected systemic structural and institutional policy failures resulting from the merger of business and development aid to learn why such situations occur and why the policies that underpin them are so difficult to redirect once their impacts begin to negatively impact a fragile host society. These failures are influenced by two overlapping dynamics.

First, there are few punitive mechanisms to address deviations in practice from responsible development actions by business, either directly or indirectly. Perhaps the best example of this is the promotion by multilateral institutions ${ }^{42}$ to foreign companies-both Western MNCs and Chinese firms-to engage in joint business ventures with violent elites in Myanmar to attempt to solidify a peace dividend through economic development. Myanmar's economy grew at a 7 percent rate since 2012, but much of this growth came from foreign firms that partnered with military elites who simultaneously conducted a campaign of ethnic cleansing. ${ }^{43}$ This arrangement would seem to be a natural trigger for withdrawal by multilateral

41 Miklian (2019a).

42 Including the World Bank, Asian Development Bank, UN, and IMF.

43 Miklian (2019c). 
institutions and firms to reduce or end such ties. But given how invested the international development community is in Myanmar, such actions have not yet occurred, and there is no punitive mechanism within business-development institutions that might force the issue. Further, multilateral institutions have done no serious self-assessment of their Myanmar policies despite a growing (and at this point nearly universal) recognition that they exacerbated conflict. Instead, the business community has adopted arguments more typically used by international development actors to justify continued engagement with violent actors: even if the presence contributes to conflict; they can temper the worst abuses through discussions with government contacts; and if they were to leave, the local community would be worse off. As we will see, those arguments can be specious.

Second, development solutions by and for business that do not reach beyond the level of "ceremonial commitments" appear to have little impact in their attempts to support constructive solutions in fragile states. Institutional actors, typified most notably by the UNGC, recruit Global South firms into development initiatives hoping that they might reach a critical mass of engaged firms and development organizations that wish to "do good by doing well." While the sheer number of Global South firms that sign on as partners is impressive-rivaling their Global North counterparts-these are not collaborative ventures in any real sense of the word. The UN is neither seeking their advice on development, nor are Global South firms necessarily offering it. The resultant exchange is superficial.

This issue then explores the potential consequences of promoting this kind of superficial exchange without accountability in business and development. These sorts of initiatives can deliver positive benefits to local populations, but they are not inherently positive (nor do they inherently lack the potential for negative consequences) even though they are typically treated as such. For example, the UNGC has no accountability mechanism to assess compliance by firms to its principles, and Global South firms needn't alter any operational activities to participate; as long as they can speak about their CSR activities within the discourse of the SDGs, they are viewed as a compliant partner. There is also little incentive for Global South firms to transform ideas about responsible business: The agenda has already been set, and for firms, the rewards of participation are reaped upon signing on to such initiatives. This framework widens the gulf between idea and practice in business actions for sustainable social development and, more importantly, squanders the opportunity that organizations like the UNGC have to learn from and incorporate lessons from Global South firms to globalize their efforts and guidance for business in sustainable development.

While it would seem straightforward to extricate lessons from the most destructive initiatives or environments, in practice, this proves to be difficult. The global business community and development entities are, by and large, on 
the same side of institutional partnerships for development, and there is often little distinction between Western and non-Western firms in such engagements. More problematically for local populations, top-down business-development policies that focus on the economics of business in development typically benefit and entrench local elites through internationalization of their economies while suppressing populations that would challenge them, as this issue illustrates in Myanmar (Miklian) and Sierra Leone (Ganson and M'cleod). ${ }^{44}$ This is one arena where the inclusion of Chinese firms is likely to aggravate the problem rather than help ameliorate or otherwise internationalize it for balance. As Gonzalez-Vicente shows in this issue, China's focus on government-to-government negotiations grants local political elites with significant leeway, often to the detriment of other stakeholders. This is found to be a general pattern of Chinese engagement. Although in some cases this creates spaces for independent policymaking away from IFI conditionalities; in contexts lacking strong independent regulatory agencies or free and active civil societies, it creates opportunities for elite enrichment and abuse of power. ${ }^{45}$

\section{Conclusion and forward research 46}

Given the complexity and context-specificity of the issues at stake, the contributions in this issue intend to jointly open a range of avenues for future research. One such avenue is the meaning of the stronger business engagement with development ideas and discourses emerging from the multilateral system, and how the differences between businesses emerging from contexts characterized by different state-business relations impact local stakeholders. We still have only partial understandings of the varied and fluctuating motives, incentives, and disincentives for engagement by business in developmental efforts; how firms in fact balance tensions between CSR and other corporate goals, whether profitability or managing the political economy; whether the practice divides are best described by geography (Chinese vs. Western) or other factors, and what those are; among other intriguing avenues.

Future studies could undertake more direct analysis of institution-firm interactions, particularly to learn how decisions are made by firms to sign up to multilateral initiatives. Despite a wide gap in rhetoric about social impact (where, e.g., Western firms are vocal and Chinese firms are quiet), there is little evidence of a grand moral divide between Western and Global South firms on social

44 Ganson and M'cleod (2019).

45 Banik and Bull (2018).

46 Special thanks to Brian Ganson for his suggestions in this section. 
development in practice. ${ }^{47}$ Several of our articles deliver interesting findings on this, but more systematic study is needed. Likewise for the impact of businessdevelopment synergies beyond participation, for instance, by studying relationships between business engagement and conflict. Studies are needed at the institutional level of agencies like the UNGC itself, to learn better why businesses came to be seen as an essential partner and help challenge or confirm the growing body of anecdotal evidence on the topic.

In addition, future work could unpack the importance and meaning of variations within Chinese firms, as they are far from monolithic. This could be through existing lenses whereby we discuss and study the interaction effects of very large companies that engage in both responsible and irresponsible behavior at the same time, or through developing new theoretical approaches. Understanding the transformation and adaptation of Chinese or "Southern" companies as they learn in different ways may better help us learn what the future of CSR brings as a heuristic. While the BRI and other Chinese initiatives, such as the Asia Infrastructure Investment Bank, may facilitate "trilateral cooperation" involving host countries, Chinese/Southern companies, and Western/DAC businesses, the relative impact of these initiatives upon host populations remains unclear. ${ }^{48}$

Collectively, more systemic - and more nuanced-study of how Global South firms operationalize development is essential. The recent uptake of CSR among Global South MNCs paves the way for large-scale quantitative studies of nonWestern companies to compare their behavior to that of their Western peers. Likewise, re-exploring the role of philanthropy in CSR and sustainable development holds considerable promise, as it looks to remain the preferred vehicle for engagement by Chinese and Indian firms in particular.

Finally, we should also more deeply assess how effective the SDGs are as a vehicle for shaping the private sector. Advocates are trying to bootstrap on "a global consensus"; but how well does that argument work on the private sector to affect meaningful change ${ }^{49}$ Tracing the policymaking process on business in development in institutional actors beyond the UN and its various initiatives would be rewarding. In both norms and practice, the position commonly claimed to be that of the "West" is often more accurately more represented-in terms of involvement, advocacy, dollars, norm development, and even impactby IFIs and the OECD than by the UN and its agencies. IFIs, their rivalries, and their impacts on companies and on development are significantly understudied vis-à-vis their impact on global development engagement by and for business.

47 Barkemeyer and Miklian (2019).

48 See, e.g., McEvan and Mawdsley (2012).

49 Ganson et al. (2019). 
Returning to our opening discussion, the emphasis by multilateral institutions on involving business more directly in development efforts that began in the 1990s was a response to particular challenges, including the weakened ability and willingness by states to cushion their local populations from the effects of unfettered capitalism in the face of weak global regulations. These challenges remain, while a number of additional challenges, such as climate change, the loss of biodiversity, and increasing inequalities, have arisen, and laid evident not only the need for business engagement but also the insufficiency of it, if it is not complemented by strong engagement by states and multilateral institutions. But what "strong engagement" means is complicated by the growth of non-Western state-capital nexuses and their increasing importance to global economic development policy. The interaction between these and other actors (including civil society) on development outcomes has been a conundrum since the initiation of the post-World War II global development efforts. The intention of this special issue has been to shed light on these debates and open up the possibility for new questions that help us better understand the meaning and practice of business in global development.

\section{References}

Amsden, Alice. 2001. The Rise of the Rest: Challenges to the West from Late Industrialized Countries. Oxford: Oxford University Press.

Banik, Dan, and Benedicte Bull. 2018. "Chinese Engagement in Africa and Latin America: Does It Matter for State Capacity?” Third World Thematics: A TWQ Journal (2018): 1-20.

Banik, Dan, and Ka Lin. 2019. "Business and Morals: Corporate Strategies for Sustainable Development in China." Business \& Politics forthcoming.

Barkemeyer, Ralf. 2019. "Csr and Governance: Of Mirrors and Substitutes.” Business \& Politics forthcoming.

Barkemeyer, Ralf, Diane Holt, Lutz Preuss, and Stephen Tsang. 2014. "What Happened to the 'Development' in Sustainable Development? Business Guidelines Two Decades after Brundtland." Sustainable Development 22 (1): 15-32.

Barkemeyer, Ralf, and Jason Miklian. 2019. "Responsible Business in Myanmar: Comparing Perceptions from Domestic and Foreign Firms." Sustainability 11 (3): 598.

Balassa, Bela. 1982. Development strategies in semi-industrial economies. Washington, D.C.: World Bank.

Berliner, Daniel, and Aseem Prakash. 2015. ““Bluewashing” the Firm? Voluntary Regulations, Program Design, and Member Compliance with the United Nations Global Compact.” Policy Studies Journal 43 (1): 115-38.

Bexell, Magdalena, and Ulrika Mörth (eds.). 2010. Democracy and Public-Private Partnerships in Global Governance. London and New York: Palgrave.

Biermann, Frank, Norichika Kanie, and Rakhyun E. Kim. 2017. "Global Governance by GoalSetting: The Novel Approach of the Un Sustainable Development Goals." Current Opinion in Environmental Sustainability 26-27: 26-31. 
Biersteker, Thomas J., and Bruce Hall. 2002. The Emergence of Private Authority in Global Governance. Cambridge: Cambridge University Press.

Bull, Benedicte. 2015. “The 'Rise of the Rest' and He Revenge of 'Developmnet': The Emerging Economies and Shifts in Development Theory." In Emerging Economies and Challenges to Sustainability: Theories, Strategies, Local Realities, edited by Arve Hansen and Ulrikke Wethal, 19-33. London and New York: Routledge.

Bull, Benedicte, and Morten Bøås. 2012. "Between Ruptures and Continuity: Modernisation, Dependency and the Evolution of Development Theory." Forum for Development Studies 39 (3): 319-36.

Bull, B. and M. Bøås (eds.). 2010a. International Development: Dependency and Underdevelopment. London: Sage.

Bull, B. and M. Bøås (eds.). 2010b. International Development: Teories of Modernization and Economic Growth. London: Sage.

Bull, Benedicte, and Morten Bøås (eds.). 2010c. International Devleopment: Feminism, human development, post-development., volume IV. London: Sage.

Bull, Benedicte, and Desmond McNeill. 2007. Development Issues in Global Governance: PublicPrivate Partnerships and Market Multilateralism. London and New York: Routledge.

Bøås, Morten, and Desmond McNeill. 2003. Global Institutions and Development: Framing the World? New York: Routledge.

Cutler, A. C., V. Haufler, and T Porter. 1999. Private Authority and International Affairs. New York: State University of New York Press.

de Graaff, Naná, and Bastiaan van Apeldoorn. 2017. "Us Elite Power and the Rise of 'Statist' Chinese Elites in Global Markets." International Politics 54 (3): 338-55.

Fukuda-Parr, Sakiko and Desmond McNeill. 2019. "Knowledge and Politics in Setting and Measuring the SDGs." Global Policy, forthcoming.

Ganson, Brian, Sarah Cechvala, Jason Miklian and Ben Miller. 2019. A Seat at the Table: Capacities and Limitations of Private Sector Peacebuilding. Cambridge: CDA Collaborative Learning.

González-Vicente, Ruben. 2019. "Make Development Great Again? The Belt and Road Initiative, Chinese Conglomerated Investments, and Their Overseas Developmental Impacts.”. Business \& Politics forthcoming.

Helleiner, Eric. 1996. States and the Reemergence of Global Finance: From Bretton Woods to the 1990s. Ithica, NY: Cornell University Press.

Helleiner, E. (2019). "The life and times of embedded liberalism: legacies and innovations since Bretton Woods." Review of International Political Economy 1-24.

Ikenberry, G. John. 2018. “The End of Liberal International Order?” International Affairs 94 (1): 7-23.

Kruger, Anne 0. 1978. Foreign trade regimes and economic development: Liberalization attempts and consequences. Cambridge, MA: Balinger.

Matten, Dirk. 2004. "The Impact of the Risk Society Thesis on Environmental Politics and Management in a Globalizing Economy - Principles, Proficiency, Perspectives." Journal of Risk Research 7 (4): 377-98.

Mattlin, Mikael, and Matti Nojonen. 2015. "Conditionality and Path Dependence in Chinese Lending." Journal of Contemporary China 24 (94): 701-20.

Mayer, Fredrick, and Gary Gereffi. 2010. "Regulation and Economic Globalization: Prospects and Limits of Private Governance." Business and Politics 12 (3): 1-25.

McEwan, Cheryl, and Emma Mawdsley. 2012. "Trilateral Development Cooperation: Power and Politics in Emerging Aid Relationships.” Development and Change 43 (6): 1185-209. 
Miklian, Jason. 2019a. "Contextualizing and Theorizing Economic Development, Local Business and Ethnic Cleansing in Myanmar." Conflict, Security and Development 19 (1): 55-78.

Miklian, Jason. 2019b. "Business, Peace and Human Rights in the Donald Trump Era." Global Policy (January).

Miklian, Jason. 2019c. "The Role of Business in Sustainable Development and Peacebuilding: Observing Interaction Effects." Business \& Politics, forthcoming.

Miklian, Jason. 2017. "Mapping Business-Peace Interactions: Opportunities and Recommendations" Business, Peace \& Sustainable Development 10 (1): 3-27.

Miklian, Jason, Rina Alluri, and John Katsos (eds.). 2019. Business, Peacebuilding and Sustainable Development. London: Routledge.

Miklian, Jason, Peer Schouten, Cindy Horst, and Øystein Rolandsen. 2018. "Business and Peacebuilding: Seven Ways to Maximize Positive Impact." In PRIO Reports. Oslo: Prio.

Moon, Jeremy, and Xi Shen. 2010. "Csr in China Research: Salience, Focus and Nature." Journal of Business Ethics 94 (4): 613-29.

O’Connor, C., and S. Labowitz. 2017. “Measuring Human Rights Performance for Investors.” New York: NYU Stern.

Oetzel, Jennifer, and Jason Miklian. 2017. "Multinational Enterprises, Risk Management, and the Business and Economics of Peace." Multinational Business Review 25 (4): 270-86.

Ougaard, Morten, and Anna Leander (eds.). 2010. Business and Global Governance. Oxon, United Kingdom and New York: Routledge.

Pattberg, Philipp. 2005. "The Institutionalization of Private Governance: How Business and Nonprofit Organizations Agree on Transnational Rules." Governance 18 (4): 589-610.

Richmond, Oliver P. 2017. "Peace in the Twenty-First Century: States, Capital, and Multilateral Institutions Versus Positionality Arbitrage, Everyday Mobility, Networks, and MultiVerticality." Globalizations 14 (6): 1014-28.

Ruggie, J. G. 1982. "International regimes, transactions, and change: embedded liberalism in the postwar economic order." International Organization 36 (2): 379-415.

Ruggie, John G. 2008. “Embedding Global Markets: An Enduring Challenge.” In Taking Embedded Liberalism Global: Thee Corporate Connection, edited by John G. Ruggie, 231-53. Hampsted and Burlington: Ashgate.

Ruggie, John G. 1997. "Globalization and the Embeded Liberalism Compromise: The End of an Era?." Max Planck Institute for the Study of Societies 97 (1).

Schneider, Ben Ross. 2016. "Desinging Industrial Policy in Latin America: Business-State Relations and the New Developmentalism." In Latin American Political Economy, edited by Juan Pablo Luna, Rodrigo Mardones and Andreas Feldmann. London: Palgrave Macillan.

Schouten, P., and J. Miklian. 2018. "The Business-Peace Nexus: 'Business For Peace' and the Reconfiguration of the Public/Private Divide in Global Governance." Journal of International Relations and Development, forthcoming and online first.

Stuenkel, Oliver. 2016. Post Western World. Cambridge: Polity Press.

Tesner, Sabine, and Georg Kell. 2000. The United Nations and Business: A Partnership Recovered. New York: St. Martin's Press.

van Apeldoorn, Bastiaan, Naná de Graaff, and Henk Overbeek. 2012. "The Reconfiguration of the Global State-Capital Nexus." Globalizations 9 (4): 471-86.

Yang, Xiaohua, and Cheryl Rivers. 2009. "Antecedents of Csr Practices in Mncs' Subsidiaries: A Stakeholder and Institutional Perspective." Journal of Business Ethics 86 (2): 155-69.

Zhang, Xin. 2017. "Chinese Capitalism and the Maritime Silk Road: A World-Systems Perspective." Geopolitics 22 (2): 310-31. 